\title{
High-Performance Liquid Chromatographic Determination of Yohimbine in Serum by Chemiluminescence Detection
}

\author{
Ryoko ChIBA ${ }^{\dagger}$, Mime ShInRIKI, Yoko IshII and Akira Tanaka \\ Laboratry of Drug Analysis, Showa College of Pharmaceutical Sciences, Machida, Tokyo 194-8543, Japan
}

\begin{abstract}
An ion-pair high-performance liquid chromatography with chemiluminescence detection using tris(2,2'-bipyridyl)ruthenium(II) $\left[\mathrm{Ru}(\mathrm{bpy})_{3^{2+}}\right]$ was developed for the determination of yohimbine $(\mathrm{YOH})$ in human serum. A sample solution, containing narceine as an internal standard, was treated with a Bond-Elut Certify disposable column, and the purified fraction was separated on a TSKgel ODS-80Ts column. The recovery of $\mathrm{YOH}$ at $50 \mathrm{ng} / \mathrm{ml}$ was $97.2 \pm 4.4 \%$ (mean $\pm \mathrm{SD}, n=5$ ). The detection limit was calculated to be $30 \mathrm{ng} / \mathrm{ml}$ of $\mathrm{YOH}$ in serum $(S / N=3)$. The method was successfully applied to drug monitoring of the $\mathrm{YOH}$ level in the serum of healthy volunteers.
\end{abstract}

Keywords Yohimbine, serum, high-performance liquid chromatography, chemiluminescence, ruthenium

Yohimbine (YOH), methyl $17 \alpha$-hydroxyyohimban$16 \alpha$-carboxylate, is an indole alkaloid obtained from various botanical sources. It has been studied for over 100 years, and is popularly believed to have aphrodisiac properties. $\mathrm{YOH}$ is an $\alpha_{2}$-adrenergic antagonist ${ }^{1}$ and has been used to study $\alpha_{2}$-adrenoreceptors in humans. ${ }^{2}$ As might be expected for this interesting compound, several chromatographic methods have been reported for the determination of $\mathrm{YOH}^{3-8}$ In these methods, either a fluorescense detector or an electrochemical detector is employed because of its high sensitivity and selectivity.

Recently a chemiluminescence (CL) detection system using tris(2,2'-bipyridyl)ruthenium(II), $\mathrm{Ru}(\mathrm{bpy})_{3}{ }^{2+}$, as a chemiluminescent reagent has been shown to be a sensitive and selective detection technique in high-performance liquid chromatography (HPLC) and flow injection analysis for the determination of aliphatic and alicyclic tertiary amines ${ }^{9-13}$, oxalate ${ }^{14-16}$ and indoles. ${ }^{17}$ For the preparation of unstable $\mathrm{Ru}(\mathrm{bpy})_{3^{3+}}$ from stable $\mathrm{Ru}(\mathrm{bpy}) 3_{3}{ }^{2+}$, three methods were reported using a batch electrochemical reactor ${ }^{13}$, an on-line electrochemical reactor ${ }^{17}$ and an electrogenerated CL flow cell. More recently, Yamazaki et al. showed that an on-line photochemical reactor could be applicable for the purpose of preparation. ${ }^{18}$ As shown in Fig. 1, YOH has a tertiary amine and an indole moiety; therefore, HPLC with CL detection using the ruthenium complex can be expected to be applicable for determining $\mathrm{YOH}$.

We described here a HPLC method for the determination of $\mathrm{YOH}$ in serum with CL detection after solidphase extraction of the analyte. This method was applied to pharmacokinetic studies of $\mathrm{YOH}$ in healthy volunteers.

† To whom correspondence should be addressed.

\section{Experimental}

\section{Materials}

$\mathrm{YOH}$, narceine (NAR), tris(2,2'-bipyridyl)ruthenium (II) chloride hexahydrate $\left[\mathrm{Ru}(\mathrm{bpy})_{3} \mathrm{Cl}_{2} \cdot 6 \mathrm{H}_{2} \mathrm{O}\right]$, potassium peroxodisulfate $\left(\mathrm{K}_{2} \mathrm{~S}_{2} \mathrm{O}_{8}\right)$ were purchased from Aldrich Chemical Co. (Milwaukee, WI, USA). HPLCgrade methanol and water were purchased from Tokyo Kasei Co. (Tokyo, Japan). All other reagents were of highest grade commercially avaiable. The mobile phase of HPLC was passed through a $0.45-\mu \mathrm{m}$ filter prior to use. A Bond-Elut Certify disposable column was purchased from Varian Co. (Harbor City, CA, USA)

\section{Apparatus and operating conditions}

The HPLC-CL system consisted of two HPLC pumps (JASCO Model PU-880, JASCO, Co. Ltd., Tokyo, Japan), a photo-reactor assembled with an ultraviolet lamp (4 W), a coiled PTFE tube $(0.5 \mathrm{~mm}$ i.d. $\times 8 \mathrm{~m})$, an<smiles>COc1ccc(C(=O)Cc2c(CCCN(C)C)cc3c(c2OC)OCO3)c(C(=O)O)c1OC</smiles>

Fig. 1 Chemical structures of yohimbine and narceine. 
S-3400 chemiluminescence detector (flow cell, $100 \mu$, Soma Kogaku, Hinode, Tokyo, Japan), a Rheodyne Model 7125 injector (Rheodyne, Inc., Cotati, CA, USA) with an effective volume of $20 \mu \mathrm{l}$ and an LR4220 recorder (Tosoh, Co. Ltd., Tokyo, Japan). A TSKgel ODS-80Ts (4.6 mm i.d. $\times 150 \mathrm{~mm}$, Tosoh) was used as the analytical column with a guard-column of TSKguardgel ODS-80Ts $(3.2 \mathrm{~mm}$ i.d. $\times 15 \mathrm{~mm}$, Tosoh). The column was maintained at $40^{\circ} \mathrm{C}$ by a CO- 8020 column oven (Tosoh). A mixture of methanol and $25 \mathrm{mM}$ phosphate buffer solution ( $\mathrm{pH} 3.5)(45: 55, \mathrm{v} / \mathrm{v})$ containing $10 \mathrm{mM}$ sodium 1-heptanesulfonate was used as a mobile phase. The reagent solution, $25 \mathrm{mM}$ phosphate buffer ( $\mathrm{pH} \mathrm{3.5)} \mathrm{containing} 1 \mathrm{mM} \mathrm{Ru}(\mathrm{bpy})_{3} \mathrm{Cl}_{2}$ and 1 $\mathrm{mM} \mathrm{K} \mathrm{S}_{2} \mathrm{O}_{8}$, was stored in a cooler $\left(5^{\circ} \mathrm{C}\right)$. Although a $2 \mathrm{mM} \mathrm{Ru}(\mathrm{bpy})_{3} \mathrm{Cl}_{2}$ solution gave a somewhat greater CL signal, the $1 \mathrm{mM}$ solution was used to save the reagent. The flow-rate used for these experiments was $0.5 \mathrm{ml} / \mathrm{min}$.

\section{Extraction procedure}

To $1 \mathrm{ml}$ of serum (or standard solution) placed in a 15 $\mathrm{ml}$ teflon-lined screw-capped culture tube, $1 \mathrm{ml}$ of internal standard solution (NAR: $25 \mathrm{ng} / \mathrm{ml}$ ) and $3 \mathrm{ml}$ of $100 \mathrm{mM}$ phosphate buffer ( $\mathrm{pH}$ 6.0) were added. After mixing for $5 \mathrm{~min}$, the contents were applied to a BondElut Certify disposable column, which was conditioned by passing $2 \mathrm{ml}$ of $100 \mathrm{mM}$ phosphate buffer (pH 6.0) followed by $4 \mathrm{ml}$ of methanol before use. The column was washed with $1 \mathrm{ml}$ of water, $0.5 \mathrm{ml}$ of $1 \mathrm{M}$ acetic acid and $0.1 \mathrm{ml}$ of methanol. The fraction of interest was then eluted with $2 \mathrm{ml}$ of a $2 \%$ methanolic ammonia solution. The fraction was evaporated to dryness under a stream of nitrogen gas at $40^{\circ} \mathrm{C}$. The residue was dissolved in $0.25 \mathrm{ml}$ of the mobile phase; $20 \mu \mathrm{l}$ of this solution was injected onto the HPLC apparatus.

\section{Standard solutions and calibration}

Known amounts of $\mathrm{YOH}$ in the range $50-1000$ $\mathrm{ng} / \mathrm{ml}$ were added to blank serum samples and treated according to the described procedure. A calibration graph was constructed by plotting the peak height ratio of YOH to NAR (I.S.) against the concentration of $\mathrm{YOH}$.

\section{Recovery test for $\mathrm{YOH}$}

The spiked samples were prepared by adding 50, 500, and $1000 \mathrm{ng} / \mathrm{ml}$ of $\mathrm{YOH}$ to the blank serum. The solidphase extraction and HPLC were carried out as described above. The recovery was determined by comparing the peak heights obtained from samples with those obtained after direct injection of $\mathrm{YOH}$ dissolved in the mobile phase.

\section{Application to pharmacokinetics studies}

The method was used to quantitate the serum concentration of $\mathrm{YOH}$ in a single-dose pharmacokinetic study. The subjects were two healthy male volunteers who gave a written, informed consent. Two subjects took 12 $\mathrm{mg}$ of Sutorupin M brand of $\mathrm{YOH}$ (Matsuda) in a fasting state. A 5-ml sample of blood was drawn at 0.25 , $0.5,1,1.5,2,3$ and $4 \mathrm{~h}$ after oral administration. Serum was separated by centrifugation at $3000 \mathrm{~g}$ for 15 min and stored at $-20^{\circ} \mathrm{C}$ until analysis. The total area under the observed serum concentration-time curve (AUC) was calculated by using the linear trapezoidal rule. A terminal elimination half-life was obtained directly from the one-compartment model. The peak serum level $\left(C_{\max }\right)$ was obtained directly from the profile.

\section{Results and Discussion}

The optimun $\mathrm{pH}$ for the $\mathrm{CL}$ reaction of $\mathrm{YOH}$ was determined by FIA. The change in the CL intensity vs. $\mathrm{pH}$ is shown in Fig. 2. YOH was found to be most reactive at $\mathrm{pH} 3.5$, which was also the optimun range for indoles. ${ }^{17}$ The NAR response was increased at much higher pHs. Burune and Bobbitt reported that the obseved CL for amino-acids is dependent upon the $\mathrm{pHs}^{13}$, and that the CL intensity was also affected by the sorts of amines. Although the exact reaction mechanism in this method is not clear at present, the difference in the CL intensity between YOH and NAR may be presumed to be caused by some variables, i.e. chemical structures, ionization potentials, state of protonation, $\mathrm{pH}$ and $S / N$ ratio.

The reversed-phase separation of $\mathrm{YOH}$ in serum samples using a TSKgel ODS-80Ts column under acidic condition required an organic solvent with moderate elution power. The optimal content of methanol in the

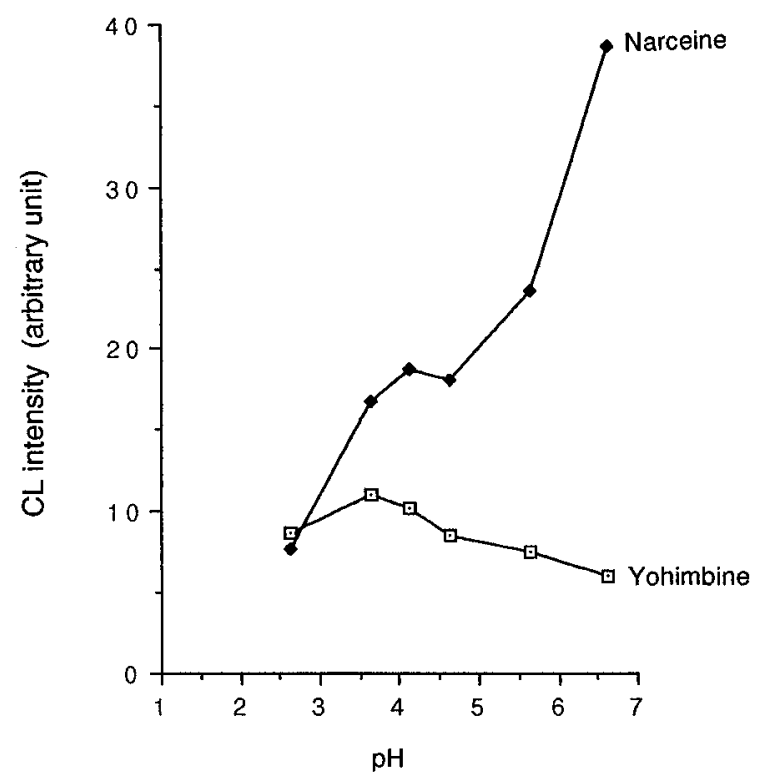

Fig. 2 Effect of the mobile-phase pH on the CL intensity, as examined by flow injection analysis. Sample concentration: YOH, 500 ng/ml; NAR, 250 ng/ml. 
mobile phase was found to be $45 \%$, providing resolution of $\mathrm{YOH}$ from endogenous substances in serum. An ion-pairing reagent, sodium 1-heptanesulfonate, was added to the mobile phase to increase the $k^{\prime}$ values. Previous HPLC methods for the determination of $\mathrm{YOH}^{4-8}$ were based on a solvent extraction of the alkaloid from biological samples; however, such procedures are tedious and time-consuming. Although a solidphase extraction (SPE) method was already reported by Akbari ${ }^{5}$, nobody reported on the SPE method for human serum. Therefore, we have attempted to establish a simple SPE method of YOH in human serum using a Bond-Elut Certify disposable column. Our developed method resulted in better recoveries of YOH: namely, 97.2 $\pm 4.4 \%, 97.3 \pm 2.7 \%$ and $98.5 \pm 1.2 \%$, (means \pm SD, $n=5$ ) at 50, 500 and $1000 \mathrm{ng} / \mathrm{ml}$, respectively (Table 1). The calibration graph for $\mathrm{YOH}$ in human serum was linear in the range $50-1000 \mathrm{ng} / \mathrm{ml}$ $(r=0.9990)$. The detection limit of $\mathrm{YOH}$ was $30 \mathrm{ng} / \mathrm{ml}$ in serum (signal-to-noise ratio=3). The relative standard deviation (RSD) was less than $4.5 \%$ at $50-1000$ ng/ml. Typical chromatograms are shown in Fig. 3.

The time course of the $\mathrm{YOH}$ concentration in serum samples from two healthy volunteers, after oral administration of $12 \mathrm{mg}$ of $\mathrm{YOH}$, was traced by the present method (Fig. 4). The pharmacokinetic parameters obtained from the two volunteers are summarized in Table 2. The $t_{\max }$ of $\mathrm{YOH}$ was $0.5 \mathrm{~h}$, and $C_{\max }$ was $74-$ $94 \mathrm{ng} / \mathrm{ml}$. The half-life value $\left(t_{1 / 2}\right)$ of $\mathrm{YOH}$ was $6.2-$ $6.4 \mathrm{~h}$. The AUC $(0-4 \mathrm{~h})$ value was $200-215 \mathrm{ng} \mathrm{h}$ $\mathrm{ml}^{-1}$. The $t_{\max }$ of $\mathrm{YOH}$ in the present study was similar, although the intake doses were different from those reported in references..$^{3,7}$

In conclusion, the combination of HPLC with the CL detection system using the ruthenium complex and solid-phase extraction by the Bond-Elut Certify disposable column was shown to be successfully applicable to the determination of $\mathrm{YOH}$ in serum, without any interference from other coexisting substances. Although the present CL method is about 7-times inferior to our pre-

Table 1 Recovery of $\mathrm{YOH}$ added to human blank serum $(n=5)$

\begin{tabular}{cccc}
\hline Added/ng ml & $\begin{array}{c}\text { Found/ng ml } \\
(\text { mean } \pm \text { SD })\end{array}$ & $\begin{array}{c}\text { Recovery,\% } \\
(\text { mean } \pm \text { SD })\end{array}$ & RSD, \% \\
\hline 50 & $48.7 \pm 2.3$ & $97.2 \pm 4.4$ & 4.5 \\
500 & $486.7 \pm 13.5$ & $97.3 \pm 2.7$ & 2.8 \\
1000 & $985.2 \pm 12.0$ & $98.5 \pm 1.2$ & 1.2 \\
\hline
\end{tabular}

vious fluorescence method ${ }^{6}$ in sensitivity, its sensitivity will be sufficient for pharmacokinetic studies. Several advantages of the CL method are as follows: (1) Many samples can be processed at the same time, and the operation time can be shortened. (2) Due to higher selectivity, better reproducibility and resolution are obtained owing to less interference by other substances in the serum. This method would be useful for the

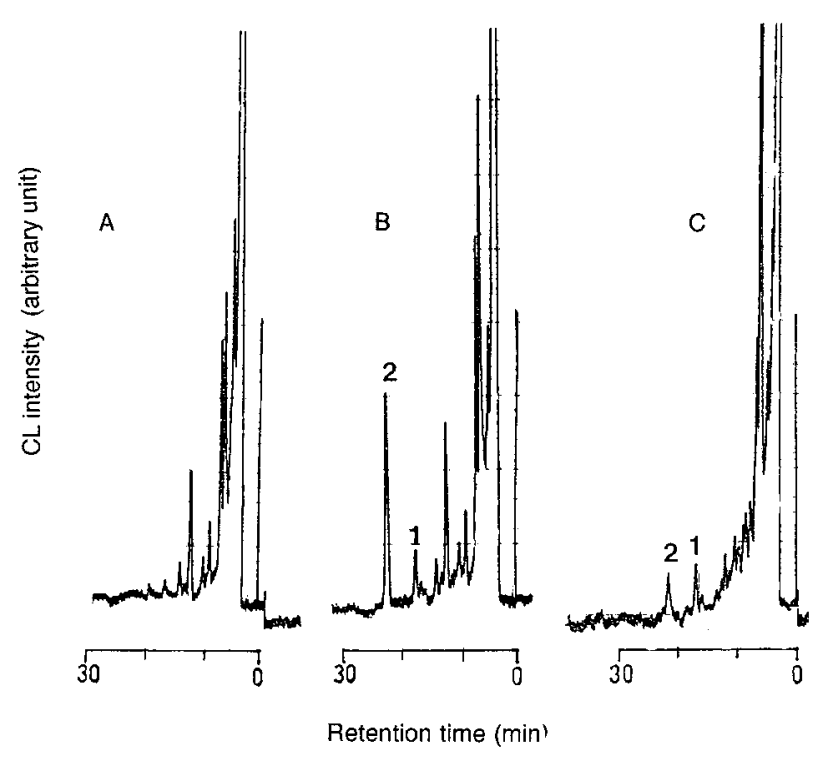

Fig. 3 Typical chromatograms of (A) blank serum, (B) spiked serum with YOH $(250 \mathrm{ng} / \mathrm{ml})$ and NAR (I.S.) and (C) serum after oral administration of YOH (12 mg). Peak: 1, NAR (16.58 min); 2, YOH (21.42 min).

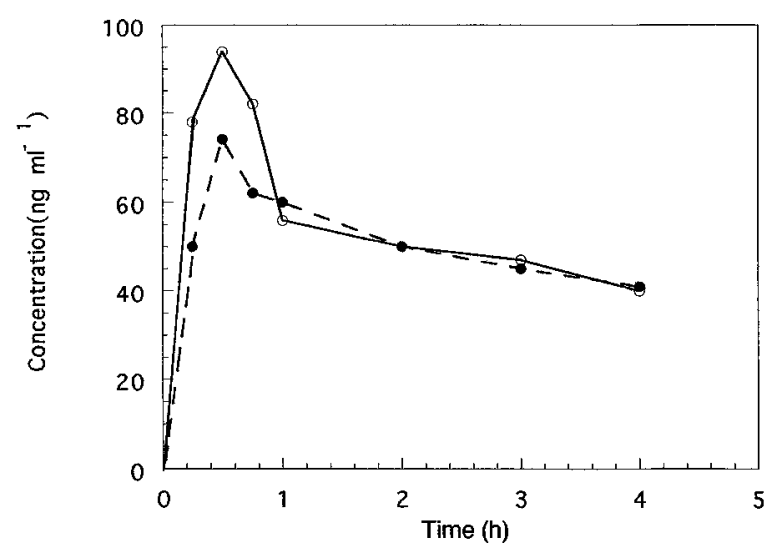

Fig. 4 Serum concentration-time profiles of $\mathrm{YOH}$ after single $12 \mathrm{mg}$ oral dose of $\mathrm{YOH}$ to two healthy volunteers. Symbol: open, subject A; closed, subject B.

Table 2 Pharmacokinetic parameters of $\mathrm{YOH}$ after oral dose of $12 \mathrm{mg} \mathrm{YOH}$ to two healthy volunteers

\begin{tabular}{ccccccc}
\hline Subject & $\begin{array}{c}\text { Age/ } \\
\text { years }\end{array}$ & $\begin{array}{c}\text { Weight/ } \\
\mathrm{kg}\end{array}$ & $\begin{array}{c}C_{\max } / \\
\mathrm{ng} \mathrm{ml}^{-1}\end{array}$ & $\begin{array}{c}\mathrm{AUC}(0 \rightarrow 4) / \\
\mathrm{ng} \mathrm{h} \mathrm{ml}^{-1}\end{array}$ & $\begin{array}{c}K_{\mathrm{el}} / \\
\mathrm{h}^{-1}\end{array}$ & $\begin{array}{c}t_{1 / 2} \mathrm{el} / \\
\mathrm{h}\end{array}$ \\
\hline $\mathrm{A}$ & 24 & 65 & 94 & 215 & 0.109 & 6.4 \\
B & 28 & 70 & 74 & 200 & 0.112 & 6.2 \\
\hline
\end{tabular}


analysis of other biological samples with a complicated matrix.

\section{References}

1. R. C. Hatch, N. H. Booth and J. V. Kitzman, Am. J. Vet. Res., 44, 417 (1983).

2. D. S. Charney, G. R. Heninger and D. E. Sternberg, Life Sci, 30, 2033 (1982).

3. J. A. Owen, S. L. Nakatsu, M. Condra, D. H. Surridge, J. Fenemore and A. Morales, J. Chromatogr., 342, 333 (1985).

4. B. Diquet, L. Doare and G. Gaudel, J. Chromatogr., 311, 449 (1984)

5. A. Akbari, A. D. Jernigan, P. B. Bush and N. H. Booth, J. Chromatogr., 361, 400 (1986).

6. R. Chiba and Y. Ishii, Bunseki Kagaku, 39, 313 (1990).

7. M. Hariharan, S. Guthrie, E. K. Kindt, T. V. Noord and L. J. Grunhaus, J. Liq. Chromatogr., 14, 351 (1991).

8. G. Reimer, A. Suarez and Y. C. Chui, J. Anal. Toxico., 17,
178 (1993).

9. J. B. Noffsinger and N. D. Danielson, Anal. Chem., 59, 865 (1987).

10. G. M. Greenway, A. W. Knight and P. J. Knight, Analyst[London], 120, 2543 (1995).

11. J. Holeman and N. D. Danielson, J. Chromatogr., 679, 277 (1994).

12. M. A. Targove and N. D. Danielson, J. Chromatogr. Sci., 28, 505 (1990).

13. S. N. Brune and D. R. Bobbitt, Talanta, 38, 419 (1991).

14. K. Uchikura, Bunseki Kagaku, 39, 323 (1990).

15. I. Rubinstein, C. R. Martin and A. J. Bard, Anal. Chem., 55, 1580 (1983).

16. D. R. Skotty and T. A. Nieman, J. Chromatogr., 665, 27 (1995).

17. K. Uchikura and M. Kirisawa, Chem. Lett., 1991, 1373.

18. T. Shinozaki, S. Yamazaki and T. Tanimura, Chromatography, 14, 60 (1993).

(Received March 19, 1998) (Accepted June 11, 1998) 